\section{An inconvenient legacy: \\ corporatism and \\ Catholic culture \\ from Fascism to \\ the Republic}

\author{
Maurizio Cau [*] \\ [*] Istituto Storico Italo-Germanico - Trento \\ - Itália. \\ E-mail:mcau@fbk.eu
}

ORCID: https://orcid.org/0000-0002-2973-1574

\begin{abstract}
In the Italian Republic of the late 1940s, the corporatist experience was something of an antimodel. However, some political and legal currents in Italy reflected on the corporatist legacy and on the possibility to make it democratic. Certain Catholic exponents were especially sensitive to the new version of corporatism. Our analysis of the legacy of corporatist thinking in Catholic culture during the early Republican age will be fourfold: reflection on the Constituent Assembly as a potential development away from corporatism; analysis of the main social-economic documents of contemporary political Catholicism; the evolution of some leading Christian Democrats' theoretical ideas; the debate on "democratic corporatism" in Italian Catholic circles spanning the late 1940s and early 1950s.
\end{abstract}

Keywords: Corporatism; Catholic culture; Democratic corporatism; Italian Republic.

\section{Um legado inconveniente: corporativismo e cultura católica do Fascismo à República}

Resumo: Na República italiana do final dos anos 40, a experiência corporativista era vista como um antimodelo. No entanto, algumas correntes jurídicas e políticas na Itália refletiam sobre o legado corporativista e a possibilidade de tornálo democrático. Alguns expoentes católicos eram especialmente sensíveis à nova versão de corporativismo. O presente trabalho analisa o legado do pensamento corporativista na cultura católica durante os primeiros anos da era republicana em quatro etapas: uma reflexão sobre a Assembleia Constituinte como um desenvolvimento potencial à parte do corporativismo; uma análise do principais documentos socioeconômicos do Catolicismo político contemporâneo; a evolução de algumas das principais ideias teóricas de Democratas Cristãos; o debate sobre "corporativismo democrático" nos círculos católicos italianos no final dos anos 40 e no início dos anos 50.

Palavras-chave: Corporativismo; Cultura católica; Corporativismo democrático; República italiana. 


\section{Foreword}

$\mathrm{H}$ istorians have recently shown a new interest in fascist corporatism, enabling light to be thrown on an institutional and cultural experience that was central to Italy between the two world wars. Much still remains to be done, but, from long being underrated, the corporative phenomenon has now emerged in all its contours (Gagliardi, 2010; Santomassimo, 2006; Stolzi, 2007; Cassese, 2010; Pasetti, 2016).

The days are past when fascist corporatism was simply seen as a clumsy experiment in institutional rhetoric, or an inconclusive medley of authoritarian administrative structures. It is now beginning to be viewed as part of a broader historical phenomenon. The worldwide success of corporatism between the 1920s and the 1950s makes it clear that this was a political and ideological project arising in response to the crisis of liberal parliamentarianism, a new way of settling social bones of contention and a new approach to political representation (Costa Pinto, 2017, p. 3-15).

As a corrective to any idea of corporatism being a mere access of fascist propaganda and planning mania, one would do well to explore its development in a broader chronological sweep, including the matrix from which it sprang. The present paper concentrates on one feature, namely the way corporatism was reflected in $19^{\text {th }}-20^{\text {th }}$-century Catholic culture, with a special focus on the transition from fascist regime to early republican experiment.

Italy's experience of corporatism actually came to an end with dissolution of the fascist regime, though in the process of "working through" the authoritarian past some political programmes went on exploring the possibility of giving it a democratic facelift. In that sense, the history of corporatism is fully justified in including the debate on the corporate model and its sustainability, or otherwise in the postwar years (cf. Cerasi, 2017, p. 104-105). In what follows, the paper will analyse the downward curve of Italian corporatism from the angle of Catholic thinking, which was especially bound up with the historical development of the phenomenon. Since Catholic culture and institutions played an active role in the various forms assumed by European corporatism, this is clearly a pivotal standpoint from which to gauge the development of the corporate ideal, based on an organic mode of reorganizing society and politics, one that both pre-existed and survived fascism.

For a great many Italian Catholics the failure of fascism's corporate experiment marked the end of a century of hopes and expectations. It was a question of coming to terms not just with a failed fascist model, but with the whole evolution of social Christian thinking out of which the corporate ideal first arose as a third alternative to capitalism and socialism. Ever since the mid-19 ${ }^{\text {th }}$ century, social Catholic doctrine had been talking of regenerating society through corporate bodies: instead of capitalistic individualism, an organic social model. A brief outline of this development may, at this point, set the perspective in which to ponder the reactions of Italian Catholicism as its various branches came to terms with that legacy. 


\section{The dawn of corporatism}

It is well-established that corporatism was not the invention of politics or socio-economic thinking in the aftermath of World War I. It came back into vogue throughout Europe in the 1920s, but actually had a long history behind it, and can be traced to the $19^{\text {th }}$ century when certain currents of political Catholicism voiced their criticism of the liberal order and the legacy of the French Revolution. It was counter-revolutionary Catholic circles in France, Belgium, Austria and Germany that sparked off the corporate idea, which was to build an organic society by reviving legally recognized trade-related bodies around which social order and harmony could be achieved (Pollard 2017, p. 42-44).

By way of reaction to the conflictual turn that the socio-economic order was taking and the need for a solution to class rivalry, part of Catholic culture harked back to the prerevolutionary guild system. A kind of idealizing of medieval social order lay behind the proposals of Catholic nobles or clergy like René La Tour du Pin (1834-1924), Frédéric Le Play (1806-1882), Albert de Mun (1841-1914), Wilhelm Emmanuel von Ketteler (1811-1877), Karl von Vogelsang (1818-1890) and Franz Hitze (1851-1921). In response to the social conflict engendered by liberal individualism and the capitalist economy, their idea was to revive solidarity between workers and entrepreneurs. Catholicism's approach to the social question was conservative, anti-revolutionary and paternalistic (Vallauri, 1971, p. 15-18). The problem of poverty and mounting social unrest was attributed to political upheaval under the banner of liberty. Reorganizing society into corporations and boosting the status of occupational groups would counter the modern individual's growing isolation and redefine the Stateindividual relationship thanks to the mediation of these intermediate bodies and the spirit of collaboration, solidarity and mutual acknowledgment between bosses and workers.

To the theorists of Catholic social thinking, the crisis was not so much political or social, as moral. To offset the woes of liberal atomism, one should hark back to the Ancien Régime and its organic model of society. Instead of the highly conflictual socio-economic dialectic underpinning industrial society, one needed mediation: this would be achieved by occupational associations and would diffuse - and hence defuse - class conflict. As Franz Hitze wrote in Kapital und Arbeit und die Reorganization des Gesellschafts (1880), "the solution to the social question [...] does not lie in giving free rein to social forces, but in tying them to discipline: the watchword for the future is not individualism, but corporate association" (Hitze, 1880, p. 412).

Though of course social Catholicism came up with numerous variants over the last decades of the $19^{\text {th }}$ century, one may agree with Ketteler that "a trend towards corporation" was considered to be "a real natural necessity" (cf. Riva Sanseverino, 1951, p. 27). As the Jesuit father Liberatore argued in an article printed by Civiltà Cattolica in 1889, "the social and worker question is above all moral and religious" (Civiltà Cattolica, 1889, p. 521), 
though the effects of that bid to revive corporate order would not be confined to the moral plane, nor to the (fundamental) issue of developing a Catholic trade union movement. Advocacy of a structured social model featuring intermediate bodies was also destined to have direct consequences for politics. The other side of the corporate coin involved defining a form of political representation based on organized interests, and hence on occupational organs of representation.

All in all, as a social reform programme, it was not without its ambiguities: it entailed "theoretical uncertainty between casting forward towards an unattainable utopia and nostalgic hankering after the corporate Christian Middle Ages that were now a thing of the past" (Baggio, 2005, p. 151). The attempt to tone down the class struggle via a purely theoretical construction of society never got off the level of pure doctrine: even the mutualaid organizations and Catholic union associations that gradually formed towards the end of the century bowed more to the rules of historic reality than to those of social doctrine.

Appeals to establish a "Christian labour regime" around corporations were frequently reiterated by the theorists of corporatism, but it was Leo XIII's social encyclical in May 1891 that actually rallied the period's social Catholicism. Rerum Novarum was the papacy's official statement on matters social, though in actual fact it made little reference to the corporate model. Suppression of the guilds was blamed for isolating and weakening the working class which was defenceless against oppression by factory owners. To Leo XIII corporations mixed or purely worker - were one of the levers by which a Catholic-based society might improve the lower ranks' working conditions and boost Catholic unionism to which the encyclical gave its full blessing (Rerum Novarum, 1891; Pollard 2017, p. 44). Leo's encyclical did not so much galvanise the corporate system, as provide a dogmatic basis for the Catholic social and union movement, acknowledging as it did that interest groups (corporations) must adapt to the "advances in culture, new habits and life's growing needs" (Rerum Novarum, 1891).

While Leo's ideas targeted "still relatively backward Italian Catholic milieus" (Riva Sanseverino, 1951, p. 208), they would be picked up and deepened by Giuseppe Toniolo (1845-1918), leader of the "Christian-ethical school" and of Christian-Democrat opinion. An influential professor of political economy, Toniolo espoused the call for broader worker participation in State government via establishment of a corporate class arrangement and an occupational system of representation (Molesti, 2005). Adopting the corporate idea did not prevent Toniolo from enlarging his canvas to the whole historical background in which the Christian union movement was cast, which actually made it impracticable to set up mixed worker-owner corporations. Pending the change in social and historical conditions needed for any organic class representation to be feasible; the social Catholic movement could only take the road of union action and compete with the socialist class struggle model.

Toniolo's model of democracy - a corporate structuring of society - rested on an organicistic view of politics in which worker freedom of organization was one of the 
linchpins (Cerasi, 2017, p. 109-110). The corporate doctrine was thus beginning to overlap "with development not just of Catholic political parties, but also union movements seeking to apply the principles of social Christianity to action in defence of the workers which even clashed at times with the Church authorities themselves" (Pasetti, 2016, p. 48). The position was not so different from the "radical democracy" advocated by Romolo Murri, exponent of Catholic modernism and one of the founders of nascent Christian Democracy. To Murri, the democratic alternative to the liberal State hinged "on the theory of interest representation, a vaguely corporatist position” (Giovannini, 1981, p. 15).

The route to follow was constitution of an organic society, but in place of proper corporatism there developed the idea of a working class that could defend its own interests unaided, outside the inter-class framework of mixed labour organizations (Vallauri, 1971, p. 39-40). Slowly - and not without difficulty - the social Catholic movement thus turned into a Catholic worker movement (Riva Sanseverino, 1951, p. 230).

Partly because of accepting union competition and a system of vying among organized classes, the corporate cause lost its edge in social Catholic thinking which underwent no significant changes during the papacies of Pius X (1903-14) and Benedict XV (1914-22). Even the first Catholic political formation arising just after the First World War - the Italian Popular Party - failed to reignite any corporate projects. When Luigi Sturzo's party demanded that political representation be extended to labour formations in 1919, it was not a trampoline for any corporatist renewal, but reflected a political orientation geared to political empowerment of intermediate bodies.

\section{Catholic culture and the fascist experiment with corporatism}

The picture changed when the ideas behind corporatism were taken up Europe-wide, when a number of "technical trial runs with corporatism" (Pasetti, 2016, p. 87) were initiated, based on the establishment of economic councils and equal rights committees, and above all when the fascist experiment with corporatism got under way. The corporate project was owed to Alfredo Rocco, Minister of Justice in the Mussolini government and one of the main "architects" of the 1926 Labour Charter (Carta del Lavoro) and the corporation network. It aimed to contain the conflictual side to the class struggle within social dynamics (Simone, 2012). But the target was not just to keep social conflict within an orderly harmonious compass, but to dominate and subordinate the conflict to direct control by state authority (Gagliardi 2010; Santomassimo, 2006). In other words, Rocco's authoritarian corporatism, to which the fascist version was moulded, turned the corporate ideal "into a tool of state politics" (Stolzi, 2007, p. 32).

From the outset that fascist version proved composite in nature and ambiguous in many respects, which made it successful in widely differing ideological contexts. This was 
noted in 1933 by Don Luigi Sturzo from his London exile. Sturzo was critical of corporatism, pointing out that the success of the expression "corporate State" was largely due to its being interpretable "in whatever way best corresponds with one's own sympathies" (Sturzo, 2005, p. 103). The Sicilian priest remarked how those apparently believing in fascist corporatism numbered "pure trade unionists, reactionary capitalists, state-serving fascists, social Catholics, national socialists and so on. The company is far from homogeneous; each group, quite different and opposing, believes it matches part of its own ideal or guarantees its own interests" (ibid.). Some of the social Catholics, in particular, seemed prepared "to see the corporate State as enshrining the Christian ideal of class cooperation, as found in the medieval guilds and Arts, as well as an effective way of blocking the door to socialist experiments" (ibid.). As he would reiterate on various subsequent occasions, the word corporation no longer held its original historical value or past meaning and had very little in common with the social-Christian corporation system initiated by Ketteler and crystallizing into Rerum Novarum (ibid., p. 137).

Relations between the Catholic Church and Mussolini's regime, which swung between entente and distance, have often been described as a marriage of convenience, rather than a close alliance (Malgeri, 1994, p. 57). No simple formula sums up the relationship between the Vatican and fascism's authoritarian politics. It was compounded, first, of the Vatican failing to support the Popular Party line against fascist pressure; then a belief that it could normalise fascism and gain significant advantages for Italian Catholicism and the Church's international position; and then came the signing of a Concordat between the regime and the Holy See, the 1931 ructions over the independence of youth organizations, followed by the ambition to Christianise fascism once that rift was healed. On the part of Italian Catholics, there occurred various forms of full approval for fascist policy, and as many instances of the regime taking its distance, more or less explicitly. To some, fascism seemed to be succeeding where the old line of intransigentismo had failed - viz. by reducing the masses to obedience; to others, the authoritarian government was a betrayal of the principle of liberty and democracy upon which a large part of political Catholicism had been built.

Especially following the Pact between Holy See and regime, the issue of corporatism formed one of the most intricate junction points in Church-fascism relations. The Catholic world's attitude to fascist policy can largely be gleaned from the encyclical Quadragesimo anno, promulgated by Pius XI in 1931 on the $40^{\text {th }}$ anniversary of Rerum Novarum, with a decisive contribution from the German Jesuits Oswald Nell Breuning and Gustav Gundlach. On fascism's corporate organization of the unions, the Holy Father wrote:

"A moment's thought shows the advantages in terms of order in all that we have briefly mentioned; peaceful cooperation among classes, repression of socialist organizations and their designs, the moderating effect of a special magistracy. Lest we omit anything in matters of such moment, [...] we must nonetheless 
say we see many who fear that the State is supplanting free activities instead of confining itself to a necessary and sufficient helping hand, that the new union and corporate set-up is excessively bureaucratic and political and that, despite the general advantages we mentioned, it seems to serve particular political designs rather than usher in a better social framework" (2uadragesimo anno, 1931).

Along with basic appreciation for the fascist reform of the unions, there was, thus, no hiding concern at the undue presence of the State in economic and social life.

In the ranks of Italian Catholicism there were some, like the Jesuits of Civiltà Cattolica, who guardedly looked on fascist corporatism as implementing the principles of social Christian doctrine and giving some of its main tenets a historic interpretation; others, however, like certain members of the old Popular Party, felt that the gap between fascist corporate practice and the spirit of social Christianity could never be bridged.

Among those who sympathised with the fascist corporate experiment, one may cite the Jesuit Angelo Brucculeri, an influential spokesman for Catholic social doctrine. Contributing copiously to the pages of Civiltà Cattolica and also Studium - organ of the Graduates of Catholic Action Movement - , Fr. Brucculeri put forward a view of fascist corporatism that had close affinities with Catholic organicism and its emphasis on solidarity. He was particularly insistent on the recognizable points of agreement between the fascist project and social Catholicism, but studiously overlooked the strident contrast between the Church's recognition of social independence and the rigid state strait-jacket applied to social dynamics by fascist corporatism. In a 1934 article for Civiltà Cattolica, he wrote of the substantial "uniformity of judgment" between pontiff and Duce in their critique of capitalism. Differences there were, to be sure, but they reflected the different ambits in which the two corporate models were couched: the ethical and moral focus of social Catholicism, versus the strictly economic and political emphasis of the fascist project (Brucculeri, 1934).

A quite similar position was taken by the group that grew up at Milan's Università Cattolica around Fr. Agostino Gemelli who espoused the fascist corporate (and political) scheme and gave it a full Catholic bill of health. Catholic culture there was going through a "phase of dispersal and doctrinal vacuum" (Moro, 1979, p. 479), and there was a pronounced alignment with fascism by many Milanese intellectuals. The aim was to inject balance into the state-centred ideology of the fascist project and "contribute usefully to how corporatism was developing", applying the basic principles of Catholicism (Gemelli 1934, p. XII).

A more critical stance towards the regime came from the popular party adherents, whose opposition to fascist policies had earned them exile or debarment from political life. Politicians like Luigi Sturzo, Luigi Ferrari and Alcide De Gasperi rejected all possibility of reading social Catholicism into the fascist corporate system. An authentically (hence Christianly) corporate regime was incompatible with centralised government; besides, the fascist version of corporatism meant complete restriction of union independence and free rein to State control. 
Some of Sturzo's writings from exile describe in detail how fascist corporatism departed from Catholic social doctrine. To Sturzo, its emphasis on the political, to the detriment of the economic and social aspects, interference by the fascist party in union affairs, and Mussolini's centralising and stabilising policies were only some of the issues raised by totalitarian fascist corporatism. The crux of the matter was the lack of free action accorded to the individual and the social group: "that creates a basic imbalance which no corporate organicism can ever redress [...]. In such a State, real corporation, which makes society into a vital, harmonious, organic body, does not and cannot exist (Sturzo, 2005, p. 118).

The complex interplay between unitarism and centralism, hierarchical pluralism and solidarism, was likewise central to De Gasperi's thinking, and he devoted a number of studies to the history of corporate theory as developed in Catholic circles (cf. De Gasperi, 2007). In his attempt to build a bridge between the old guard of the Popular Party and the young Catholic intellectuals, the last secretary of the PPI went deeply into the Catholic tradition featuring Ketteler, Du Pin, De Mun, Leone XIII, Hitze and Toniolo. These he compared polemically to the state-serving distortions of fascist corporatism. Instead of being a bulwark against state intrusion, it was a tool of authoritarian government thrust upon the economic and social sphere (Santomassimo, 2006, p. 86).

In general, one may say that only limited points in common linked fascist corporatism to the Catholic model of an organic society organized into corporations. Such as they were, however, they enabled part of Catholic culture to bond with the Mussolini regime. Things would change, of course, come the demise of fascism and the ensuing collapse of the corporate experiment.

\section{The corporate legacy in a democratic context. Moving on or clinging on?}

Once the regime collapsed, this whole spectrum of doctrines seemed destined soon to disappear. That new corporate-based legal order converging on the State as the sole entity empowered to engender society must necessarily be swept away. The fascist interpretation of corporatism fell into discredit and with it a blanket condemnation of the regime's achievements. Anything that smacked directly or indirectly of the corporate experiment was thrown out of the window.

Not everyone breathed a sigh of relief to see it dismantled. Some of the leaders in that transition to a Republic lamented the betrayal of the original ideals amid the overthrow of corporation theory, and tried to revive the doctrine in a democratic perspective.

Catholic circles returned to the corporate idea at the first opportunity of resuming political debate. It was not so much what to do with the fascist corporate edifice, as how to formulate Catholic corporate principles in the broader canvas of restoring democracy. 
Before reviewing some of the cruxes of postwar Catholic politics, one needs to note a gross lacuna: in the debate we are tracing, no attention was paid to the corporate experiments that had taken off worldwide on the heels of the fascist case, especially in Europe. To Italian political thinking, it was irrelevant that Portugal, Spain, Austria and in differing forms Slovakia, France, Greece, Romania and Poland had introduced a corporate system (Pasetti, 2016, 19lff.; Costa Pinto, Kallis, 2014; Costa Pinto, 2017). If anything, it was seen as a symbol of "fascist internationalism", and not as a sign that there might be an alternative to the liberalist economy (Costa Pinto, 2017, p. 3). The only historical fruits of corporatism taken on board were those of Italian fascism, and the various hybrid versions of the phenomenon on an international scale were neither tabled nor seriously discussed. Both the detractors of corporatism and those in favour of launching a democratic version confined their analysis to Italy.

\section{Documents of Catholicism's postwar political programme}

One opportunity for comparing and conflating the social-Catholic tradition with the new challenges in economics occurred in July 1943, when the Graduates Movement of Azione Cattolica met and drew up the Code of Camaldoli, a manifesto of social Catholicism. It was to have an influence on the economic policy of the fledgling Democrazia Cristiana (Persico, 2014). The Catholic economists most wedded to the corporate tradition did not take part. The document represented a marked departure from the hitherto dominant social doctrine. One significant sign of this was the development away from the corporate idea which, though still detectable in the 1943 draft, was abandoned in the 1945 version.

In the economics section of the first statement (Enunciati) of 1943, there is explicit reference to a "well-structured" corporate system as a way of "ensuring justice in economic relations among individuals" and "making the community's economic system more efficient on organic lines whereby the individual's free enterprise is stimulated, controlled and coordinated without being violated" (Civitas, 2013, p. 49). The revised version of those tenets was the work particularly of Sergio Paronetto and Pasquale Saraceno. Over the 1930s, they had gradually moved beyond the "moralistic perspective" characterising the Catholic Graduates Movement's adoption of corporatism; they came to criticize the corporate system more on technical and economic than on doctrinal grounds (Persico, 2014, p. 16-17). The text, thus, changed significantly, making only generic reference to the "need to promote forms of collaboration between worker associations and employer associations", which gives some indication of the complex transitional phase that the theorists of social Catholicism were negotiating (Per la comunità cristiana, 1945, p. 118).

Signs of a challenge to the corporate ideal, or rather to the classic stance of social Catholicism, can also be detected in the first policy statements of incipient Christian Democracy. These began with Idee ricostruttive della Democrazia cristiana drawn up in 1942 and spring 1943 by 
Alcide De Gasperi in liaison with those former PPI members and Milanese "Guelphs" that would form the nucleus of the DC. In the section on "representation of labour-related interests and economic democracy", the document that circulated in July 1943 reads: "We are against returning to class struggle methods, but also against the present cumbersome system of corporate bureaucracy which, for reasons of political dominion, makes use of the Christian-Democratic idea of free organic cooperation among all production factors (Damilano, 1968, p. 6). In their nascent policy-line, the Catholics were to adopt the third alternative to capitalism and socialism advocated in church doctrine, but without repeating the mistakes of the failed fascist experiment. Insistence on free union membership and regulation of collective bargaining with compulsory arbitration in labour disputes were likewise points prompted by the recent authoritarian experience, recast on a would-be democratic basis.

Principles like elective representation of major national interests in the Senate, independent obligatory trade unions, free organization of work with proportional representation in unions were topics that also came up in the Milan Programme published by Christian Democracy (DC) on $25^{\text {th }}$ July 1943 as fascism toppled. References to the system of organizing interests as a way of stemming the "political and bureaucratic degeneration of the corporate idea" were also contained in the DC's Message of the Regional Committee to the people of Sicily (Damilano, 1968, p. 18), where the DC confirmed its intention to set up a system of interestgroup representation founded upon trade organizations.

The first institutional plans to emerge from party political activity likewise appealed for the establishment of organic representation of interest groups hinging on a two-chamber system. As Guido Gonella told the first DC congress in April 1946, it would enable "atomistic representation of the individual to be rounded out with organic representation of social groups" (Damilano, 1968, p. 25l).

The first party programmes thus seemed determined to make a clean break with fascist corporatism, but never went beyond upholding a system of organic representation of interest groups and the economic-political role of work-related organizations. These points would be raised and defended at the Constituent Assembly too. Indeed, that Assembly and the debate driven by Catholic politicians is the right place for a close-up view of Catholic culture (political, economic and social) and the change of tack it took as fascism gave place to republic.

\section{Corporatism under debate at the Constituent Assembly (1946-1948)}

To Italy's constituent fathers, it is evident that all explicit reference to the experience of corporatism was a blind alley. This emerges clearly from a passage in a speech by Giuseppe Saragat, leader of the Italian Social Democrat Party and President of the Constituent Assembly. He was commenting on the merits of the constitutional project in March, 1947: "This project, to me, has one [...] merit: it is a project that has avoided falling into the trap 
— and dire it might have been — of upholding representation of so-called corporate interests, the corporate forms of representation. It is my impression that wherever corporatism exists, democracy dies" (Proceedings of the Constituent Assembly, 6 March 1947). The position was shared by most political forces of the day, communists and socialists to the fore, to whom "the perilous lumber of corporatism" (words spoken by socialist Renato Tega to the Assembly) was a threat to the growing edifice of the Republican State. The same occurred at the debate over organic representation of interest groups at the Senate, even when the position was one that the socialists themselves had defended in the early 1920s, before fascism monopolized the corporate tradition.

In their turn, the Catholics rejected all notion of resuscitating the corporate mechanism in its fascist version, despite their traditional penchant for corporate culture. The majority of the Christian Democrats were clearly aligned with the Church's social doctrine, but fascist corporatism was completely discredited and revival of it had become taboo. Unless, of course, one was to go back to the "authentic" tradition of corporatism and brand the fascist experiment as the historical negation of what was still a valid social and doctrinal scheme. This is what the Christian Democrat Edoardo Clerici (among others) sought to do. On $11^{\text {th }}$ September 1947, he spoke up in the debate on formation of the Senate, arguing that there was no reason for a priori dismissal of "what I do not hesitate to call 'corporate interests'. For fascism, honourable colleagues, need not be an impediment to our doing as we think appropriate, just because it did so before us" (Atti della Costituente, 11 September 1947).

In the same breath as determined dismissal of the fascist corporate interlude, one also finds a line of thought that indirectly drew on the theory and arguments typically associated with corporatism. One clear instance of osmosis between old and new regarded the debate on the Second Chamber, where some members of the assembly (especially from the Catholic ranks) came out in favour of an interest-group Senate (cf. Argondizzo, 2009). The plan for a corporate Senate presented by Costantino Mortati was a case in point. Mortati was a leading light of Italian postwar public law who was elected to the Constituent Assembly in the ranks of the DC. He was determined the Second Chamber should include interest groups representing labour, bureaucracy and the unions.

It would be unfair to say that Mortati's plan was to restore the corporate system. In his view, citing a few cherished tenets of organicist pluralism of social-Christian memory was not in itself an attempt to renovate the past corporate edifice (cf. De Siervo, 1990, p. 301-305). The plan to extend political representation to economic and cultural categories aimed to bolster the role that work played (or ought to play) in the Italian Constitution, and not to give a new lease of life to reactionary or conservative mechanisms - which Mortati knew to be politically and historically discredited.

His actual aim was to "differentiate between the two chambers, adopting the criterion of integrating political representation" (Mortati, 1947), and avoiding the doldrums of 
perfect bicameralism (Astolfi, 2005). As he said in an interview for the DC left-wing journal Cronache sociali, the need was to balance the increasingly specialized, technicized nature of representation with "a modicum of direct intervention, carefully contrived so as to give enough protection to the general interest of organized groups" (Mortati 1947). So although it indirectly conjured up the form, it was not a revival of the corporate model but an attempt to fashion the institutions so as to achieve "greater proximity between society and State". As he would confirm in various pieces he wrote in 1951 on the subject of corporate transformation of the State and the limits thereof, the ideal of solidarity, designed to prevent and curb conflict between classes, did not in itself betoken corporatist institutional thinking (Mortati, 1951, p. 167).

Although Mortati's proposal to create a Second Chamber where the people's local and also work-related interests might find representation had no corporate designs, it must have sounded like that to the constituent fathers, even those like Mortati, who viewed an organicist society in terms of freedom. In vain might the Catholic lawyer strive to clarify the kind of representation that Second Chamber would have, political and not interest-based (Antonucci, 2007, p. 39-47). The project was allowed to drop out of the agenda by the very Catholics who had wanted it: the Christian-Democrat socio-political programme was to take a swing in another direction, breaking deliberately with the corporatist tradition which had played such a part in forming the Catholics' political platform in the late $19^{\text {th }}$ and early $20^{\text {th }}$ century (cf. Pombeni, 2016, p. 280-288).

\section{Beyond corporatism: Alcide De Gasperi and Amintore Fanfani}

To track the various stages that the corporate idea went through within the ranks of Catholic politics - often in the form of setbacks - it might pay to leaf through the profiles of certain DC leaders. Clearly, great interest attaches to that of De Gasperi, who led the DC in government from 1948 to 1953. In the late 1920s and on through the 1930s, he had laboured in broadly anti-fascist terms to defend the specifically Catholic slant to the corporate message; whereas in the latter part of the 1940s he would shed the traditionalist side to his corporate thinking and play up the solidarity emphasis (Cau, 2009).

Over the years of his banishment from public life, De Gasperi had dwelt much more on the purely political and cultural sides to the phenomenon and not so much on its concrete achievements. In many an article for Catholic periodicals, he argued the need to preserve the authentic core of corporatism against the distortion of it by the fascists. The spirit of that act of cultural conservatism is something he spelt out to his party colleagues in 1947:

"But you see, my friends, one must not get caught up in words. What counts is the spirit. When the fascist corporations were brought in, weak and over-naïve Catholics wrote that that was our programme, as ever since the $18^{\text {th }}$ century we have been heralding, pressing for and singing the praises of corporations. 
At the time I lacked the freedom to say what I thought since no newspaper, not even the Catholic ones, had the courage to print everything. So, from my bed in a clinic I studied the literature on the French corporations, the history of corporatism, and strove to show that it all depends on the spirit in which such corporations are set and behave, and one should not be dazzled by words" (De Gasperi, 2008, p. 1118).

The spirit of De Gasperi's cultural crusade in defence of the corporate ideal against the degenerate version of it under fascism flowered again soon after the war was over, when Studi e appelli della lunga vigilia was published in 1946. That collection of writings on the development of Germanic corporatism, and René de la Tour du Pin's 1930s corporatist essays, appeared at a moment when various elements of social Catholicism were being studied by the forces of political Catholicism. De Gasperi's own interpretation of the cornerstones of Catholic corporatism, including the more conservative and reactionary, had dwelt on the hostility Catholic culture had always shown for a centralising State. His essays had appeared in journals of Milan's Catholic University, as well as in Vatican periodicals. Though shackled by fascist censorship, De Gasperi's thinking shines through clearly. He was all along convinced "of Christian corporatism as an ideal, or rather a need for peace-making within society, as a basic requirement of Christianity that natural rights be respected, threatened as they were by the pagan class-ridden mythology of nationalism and the Weltanschauung of an absolute ethical State" (De Rosa, 1954, p. 12). During the fascist years, De Gasperi in this sense "uses" the corporate Catholic tradition as a way of condemning Mussolini's state-worshipping regime and defending the central importance of independent intermediate social bodies.

The collapse of fascism would actually not prompt De Gasperi to revert to the corporate ideal. There is one episode where he seems clearly to have moved beyond the corporate ambition, despite having spent the previous decade building his own brand of antifascism around it. That was the moment when De Gasperi broke from Giuseppe Toniolo, whose corporatist ideas had long served as a theoretical prop to De Gasperi's analysis.

De Gasperi was like Toniolo in that, during the years of Vatican exile under fascism, the brand of social Christian doctrine could not but be corporatist. By the late 1940s, De Gasperi's references to Toniolo's ideas have a quite different tone. In penning the preface to Toniolo's Democrazia cristiana. Concetti e indirizzi, published in Rome in 1949, the DC leader and now Prime Minister performs a thorough re-appraisal of Toniolo's brand of democratic corporatism:

"Contingency and relativity vis-a-vis the times mark this volume. The man of doctrine chronicles the passing hour and, at the end of the $19^{\text {th }}$ century tries like many another thinker and writer in other fields of thought and action to sum up developments in the previous century and set up a manifesto for the incoming one. Looking back with hindsight, we now feel that the calendar 
forced his hand; that the bold attempt to stand as arbiter between the two centuries led him into a reconstruction which events this first half-century have not always borne out" (De Gasperi, 2009, p. 1168).

As late as January 1944, as De Gasperi wrote in an article for the clandestine Catholic press, Toniolo was an obligatory benchmark for any resumption of political Catholicism. And only two years earlier, Milan's Università Cattolica had paid a glowing tribute to the Treviso economist, emphasizing "his central importance - man and work - for Catholic academics and the young generation" (Cerasi, 2014, p. 83). But, only a few years later, the central relevance of Toniolo's teaching would be cut down to size: De Gasperi's summing up of Toniolo's academic ascendancy — and by implication the corporate ideal — was in all respects an epitaph.

A second career that is worth following is that of Amintore Fanfani, elected to the Constituent Assembly among the ranks of the DC and destined to be a long-term leader on the Italian political stage. As a youthful teacher of the history of economic thought at the Milan Catholic University, he spent the 1930s campaigning for the corporatist message on which he had a rather personal slant, the references to the Catholic roots of that bundle of doctrines being rather thin on the ground (Fanfani, 1937; De Mattei, 2010, p. 23). To Fanfani, corporatism was a stepping-stone "towards a renewed form of voluntarism" (Ornaghi, 2011, p. 175-176); a tool by which to combat the "naturalism", which had hitherto underlain the theory of alleged rationality of spontaneous economics. It was the moral basis of fascist corporatism that Fanfani preached, in partial opposition to those who prioritized the political side to that corporate experiment. In his youth, Fanfani accorded the State a clear supremacy in matters economic and social, though that was not to make it an end in itself as Giovanni Gentile's neo-idealism proclaimed. Rather than asserting a claim to ethical superiority, the State ought to promote ethical goals. That was the basis of Fanfani's idea of the State as an economic and moral lodestar, an idea he would stick to in the years after the war.

The neo-voluntarist framework of Fanfani's economic thinking remained virtually unaltered over the years, despite the changes in historical reference points and the cultural models on which it rested (Roggi, 2013). The State continued to be the link between economic action and ethical principles, but in implementing that order of things one no longer looked to the fascist corporate system. To square economics with Catholicism and corporatism in the aftermath of the war, Fanfani began to eye Roosevelt's New Deal and the Keynesian model.

As early as 1946, Fanfani published a work on the US neo-voluntarism, outlining the critique levelled by certain American economists against classic liberalist theory. Fanfani had his reservations about that new American doctrine, which he thought needed a personalist correction (Nicoloso, 2001, p. 47), but his work serves to show how, consistently with his own intellectual development, he had turned the page on the corporatist chapter (Michelagnoli, 
2010; Ornaghi, 2011). Fanfani's development is a case of continuity amid rupture. This is amply borne out in his addresses to the Constituent Assembly in which he explicitly tried to steer "between the extreme of the so-called 'third way' advocated by the neo-liberals, and the extreme of 'planning' as supported among others by the collectivists" (Atti della Costituente, III sottocommissione, p. 123).

\section{Reviving the corporate argument}

We have seen one line of thought which had now turned its back on any explicit reference to Catholic corporatism. But there was another current of political and legal Catholicism that openly espoused corporatism with a democratic slant down to the early 1950s (cf. Zaganella, 2016). Clear support for a corporatist-inspired economic and social reconstruction came from Civiltà Cattolica, a journal that had always been closely connected to the office of the pontifical Secretary of State; and here it was the ambition in particular of Angelo Brucculeri and Alberto De Marco to put back the corporate idea centre-stage.

We have seen that Brucculeri was one of the most impassioned believers in compatibility between the fascist corporate regime and the essence of social Christianity. In this, he gradually changed his tune. By 1942, his criticisms of fascist corporatism concerned the departures by Mussolini's regime from Church social doctrine; during the months the Christian Democracy was forming as a political project, Brucculeri showed his aversion for the capitalist model and again argued the validity of a corporatism based "on an organic view of society, on the principle of the fundamental solidarity of the productive categories, on the postulate that governs all economic activity in harmonious agreement with the goals of the community" (Brucculeri, 1942, p. 44). A 1944 pamphlet of his on labour, as part of the Civiltà Cattolica series on the "the social doctrines of Catholicism", would argue that work would gain emancipation and enhanced social status "above all if the corporate system is restored" (Brucculeri, 1944, p. 35).

A similar line of interpretation was taken by De Marco, who first argued throughout 1945 that the national economy should adopt the liberalist model and get rid of all forms of economic planning, only to swing right over to a corporate standpoint. In July 1946, Pius XII wrote a letter to the president of the French social week in which he hinted heavily that corporatism should be seriously reconsidered as a model of economic and social development:

"We believe that the establishment of associations or corporate units, in all branches of the national economy, would be much more advantageous in the future, more advantageous at the same time to the best performance of companies. ... There is no doubt that, in the present circumstances, the corporate form of social life and especially of economic life practically favours Christian doctrine concerning the person, the community, work and private property" (Pius XII, 1947, p. 455). 
An article published by Fr De Marco at the pope's direct request (cf. Sani, 2004, p. 29-30) argued that "the corporate doctrine that the church teaches is by no means past, since it rests on the eternal principles of the Gospel and on the unchanging needs of the human spirit, principles and needs based on the supreme law of solidarity among common economic progeny" (De Marco, 1946, p. 307). Resumption of the corporate model did not figure on the political-economic agenda of the transition governments, but to the church hierarchy and their spokesmen, that was the direction in which the national economy should develop.

The Jesuit review and the Vatican hierarchy were not the only stirrers of the corporate argument. Other walks of Italian Catholicism showed interest in the fate of corporation-based social thinking in the new Republic. In that animated debate, there figured a wide gamut of important personalities in law and politics of the time, such as Luigi Sturzo, Giuseppe Dossetti, Francesco Carnelutti, Francesco Santoro Passarelli, Giovanni Tupini and Iginio Giordani. To remember this helps us appreciate the way Italian postwar culture coped with the issue of corporatism. One particularly interesting window onto this attempt to render corporatism democratic was a dispute taken up by the Catholic (and not only Catholic) press from the end of the 1940s through 1950. It took the form of a sustained exchange of articles by the DC senator Alberto Canaletti Gaudenti and Saverio De Simone, a professor of public law who had already figured in the 1930s corporatist debate. The whole exchange would be published in 1951 (S. De Simone, A. Cataletti Gaudenti, 1951). The aim was to air the prospects of a new corporatism, seen as a "system of integral social cooperation", making amends for the travesty that "royal corporatism" (meaning fascist) had made of the original corporate idea. One needed to break "the conspiracy of silence", which had shrouded the corporate experience immediately after the war. That fascist corporatism had been a failure need not condemn the corporate principle in itself, since the (Christian-inspired) path of democratic corporatism had not yet been tried.

A passage from De Simone's preface to that 1951 volume is worth citing. While rejecting the authoritarian past, it neatly describes a continuing attachment to several paradigms of corporate thinking:

"That certain historical positions should pay the penalty of defeat is historically inevitable. That, upon that defeat, we would seek to suppress everything that smacked of fascism [...] was likewise an inevitable fact. That certain values, however, cannot be suppressed when they answer a deep need of the times, is no less an incontrovertible and precise fact. Which is why we cannot suppress the principle and, with the principle, the idea of corporatism. That principle and idea, in their most intimate claims, are nothing but the principle and idea of naturally connected integral collaboration among the categories comprising society, however much fascism, starting from acceptable premises, may have gone on to provide a negative experience of corporatism. But that was merely because one could not create authentic corporatism within a grasping form of totalitarian state" (S. De Simone, A. Canaletti Gaudenti 1951, p. 10). 
One weighty example of how working through the fascist experience of corporatism helped hone Catholic social and economic policy after the war was a heated debate raging in the columns of the Giornale d'Italia. The editor Santi Savarino - who would be returned as a DC Senator in 1953 - took issue with Iginio Giordani, a prominent Catholic figure of the day. Some of Savarino's charges against the DC concerned its removal of the bases of corporatism. De Gasperi's party seemed to be reneging on the roots of social Christian thought which saw the corporation as a pillar of any organic social system. But Christian Democracy, claimed Savarino, "socially, economically and politically cannot be other than a corporation. Either that, or nothing" (ibid., p. 22). By way of reply, Iginio Giordani pointed out that "the name of corporation has been tarred by fascism; and it will take time before we can restore it to its fine medieval meaning when it signified organization of the elements of production, spiritually imbued with faith [...] But corporation in that sense is not the endpoint of the whole of Christian Democrat thinking [...]: it is one feature, albeit important" (ibid., p. 31-32).

On the sidelines of the argument, there came a contribution from Canaletti Gaudenti who, ever since joining Gerardo Bruni's social Christian movement in the early 1940s, had favoured a programme of economic and social reforms based on worker participation in business management. He too argued that social Catholicism could but culminate in the corporation; the DC, as heir to the political and social ideas of $19^{\text {th }}$-century Catholicism, ought to see corporatism as a prime tenet of its political strategy. Interclass cooperation and solidarity, the concrete upshot of DC action, was nothing but a form of corporatism, claimed Canaletti Gaudenti.

The affair even reached the columns of the DC daily Il Popolo, where some accused the Catholic party of "political apostasy" in swerving from the corporate principle, while others (like Sturzo) criticized Catholic corporatist doctrine for historically failing to deliver in real political and economic relations. The $19^{\text {th }}$-century corporate doctrines would remain "simple literature subject to theoretical speculation" (ibid., p. 60), which is why the PPI political programme following World War I discarded it as a model. The PPI's own plan to represent class organizations in the Senate was quite different from fascist corporatism, which unwary Catholics praised to high heaven as the true corrective to liberal individualism and the latter-day implementation of the Catholic-medieval cooperative tradition" (ibid., p. 61). "The whole of the Italian and foreign literature produced since the day Mussolini set up the Chamber of the Fasci and Corporations," added Sturzo trenchantly, "has fallen into oblivion today with no chance of reviving, since it was falsely grafted onto the tail-end of the social-Christian tradition; fallen, too, is the literature of those Catholic supporters who took the fascist corporate State as a kind of Catholic State and seriously believed in political corporatism (which was nonsense, or rather a contradiction in terms) and even economic autarky" (ibid.). Even the plan for a second Chamber representing the organic 
forces of the nation, as proposed to the Constituent Assembly, was not to be construed as an attempt to bring in "a kind of contraband State". As Sturzo stressed, it had nothing to do with corporate experience or theory.

This is not the place to go into all the arguments produced as to reviving the corporate idea within democracy. There is a record of them in the Convegno di Studi Sindacali, organized at the Rome Chamber of Commerce in 1949. We may sum up the main issues in the debate. Those against talked explicitly of incompatibility between organic corporatism and a pluralistic democracy; that corporatism had broadly resisted all attempts to implement it historically. Those in favour of a democratic version brought out the stock arguments that it was an alternative to liberalism and to collectivism; it expressed the most modern form of democracy (as witness the Pope's social message); and it would form a frame within which to set about decentralizing the State.

\section{Conclusion}

In the political and cultural climate of the fledgling Republic, corporatism acted as a kind of anti-model. In the name of stripping away all residue of fascism from the new political and legal set up, it was ruthlessly rejected. Yet, some walks of political and intellectual life were reluctant to abandon some of the claims of corporatism where it was least compromised with the authoritarian regime. As it has recently been pointed out, "though the term 'corporatism' was no longer usable, corporate praxis and language survived in the mentality of broad sectors of society" (Pasetti, 2016, p. 277). At the root of such echoes of corporatism, lay the "ineliminable glue of stability that always dogs transitions from one political regime to another, and the inevitable points of continuity that occur even in situations of radical change" (Gagliardi, 2010, p. 158).

It may, thus, be said that the corporate experience was a failure in broad terms, though not without effects in the medium term - effects which need to be explored in the history of post-fascist Italy. Some legal historians have recently confirmed the point: "despite its specific connections with regime policy, corporatism must be studied if we are to grasp the meaning of the great transformation that occurred across the $20^{\text {th }}$ century" (Fioravanti, 2011, p. 485).

In other words, as a historical phenomenon corporatism peters out with the failure of the fascist project, but the symbolic impact that experience had on the course of $20^{\text {th }}$-century governmentalism did not die with dissolution of the Camera dei Fasci e delle Corporazioni in August 1943. Echoes of an experiment that aimed to open up new forms of normativity and redraw the confines of modern statuality would go on reverberating well beyond the collapse of the fascist regime. 


\section{Bibliography}

ANTONUCCI, Carla. Il bicameralismo nell'opera di Costantino Mortati. In: Galizia, Mario (Ed). Forme di Stato e forme di governo: nuovi studi sul pensiero di Costantino Mortati. Milan: Giuffrè, 2007, p. 31-55.

ARGONDIZZO, Domenico. Il sistema elettorale del Senato italiano nel dibattito all'Assemblea Costituente. Quaderni dell'osservatorio elettorale, n. 62, p. 39-73, 2009. ASTOLFI, Fabrizio. Democrazia corporativa. La proposta di Costantino Mortati in Assemblea costituente. Italia Contemporanea, p. 225-247, 2005.

BAGGIO, Antonio Maria. Lavoro e dottrina sociale Cristiana: Dalle origini al Novecento. Roma: Città Nuova, 2005

BRUCCULERI, Angelo. Dal corporativismo dei cristiano-sociali al corporativismo integrale fascista. Civiltà Cattolica (Roma), v. 1, p. 449-459, 1934. 1942.

La giustizia sociale. Roma: Civiltà Cattolica,

Il lavoro. Roma: Civiltà Cattolica, 1944.

CANALETTI GAUDENTI, Alberto; DE SIMONE, Saverio. Verso il corporativismo democratico. Roma: Cacucci, 1951.

CASSESE, Sabino. Lo Stato fascista. Bologna: il Mulino, 2010.

CAU, Maurizio. La via maestra alla giustizia sociale: Alcide De Gasperi tra solidarismo e corporativismo. Scienza \& Politica, 41, p. 5-31, 2009.

Un nuovo ordine tra Stato e società: Recenti ricerche sul corporativismo. Storica, n. 48, p. 135 163,2010 .

CERASI, Laura. Corporatismo/corporativismo e storia d'Italia: Un percorso di lettura. Contemporanea, v. 4, n. 2, p. 367-377, 2001.

. Il corporativismo "normale": Giuseppe Toniolo, tra medievalismo, laburismo cattolico e riforma dello Stato. Humanitas (Brescia), v. 1, p. 82-103, 2014.

Rethinking Italian corporatism: Crossing borders between corporatist projects in the late liberal era and the Fascist corporatist state. In: CosTA PINTO, Antonio (Ed.). Corporatism and Fascism: The corporatist wave in Europe. London: Routledge, 2017, p. 103-123.

COSTA PINTO, Antonio (Ed.). Corporatism and Fascism: The Corporatist Wave in Europe. London: Routledge, 2017.
; KALLIS, Aristotle (Ed.). Rethinking Fascism and Dictatorship in Europe. Hampshire: Palgrave Macmillan, 2014.

DAMILANO, Andrea (Ed.). Atti e documenti della Democrazia cristiana (1943-1967). Rome: Cinque Lune, 1968.

DE GASPERI, Alcide. Scritti e discorsi politici. v. I-IV, Bologna: il Mulino, 2006-2009.

DE MARCO, Angelo. Ai margini della XXIII Settimana Sociale di Francia. Civiltà Cattolica, p. 304-308, 1946. DE ROSA, Gabriele. Alcide De Gasperi e il corporativismo cristiano. Rassegna di politica e di storia, n. 7, p. 7-15, 1954.

DE SIERVO, Ugo. Parlamento, partiti e popolo nella progettazione costituzionale di Mortati. In: GALIZIA, Mario; GROSSI, Paolo (Ed.). Il pensiero giuridico di Costantino Mortati. Milano: Giuffrè, 1990, p. 301-357.

FANFANI, Amintore. Il significato del corporativismo. Como: Cavelleri, 1937.

FIORAVANTI, Maurizio. Stato e Costituzione: L'esperienza del Novecento. In: Il contributo italiano alla storia del penserio. Il diritto. Rome: Enciclopedia Italiana, 2011, p. 485ss.

GAGLIARDI, Alessio. Il corporativismo fascista. Laterza: Rome-Bari, 2010.

Tra rivoluzione e controrivoluzione. L'interpretazione gramsciana del fascismo. Laboratoire Italien, n. 18, p. 1-20, 2016.

GEMELLI, Agostino. Problemi dello Stato corporativo. Milan: Vita e Pensiero, 1934.

GIOVANNINI, Claudio. Romolo Murri dal radicalismo al fascismo: I cattolici tra religione e politica (19001925). Bologna: Cappelli, 1981.

HITZE, Franz. Kapital und Arbeit und die Reorganization des Gesellschafts: Paderborn, 1880

Il Codice di Camaldoli. Civitas, 1984.

MALGERI, Francesco. Chiesa cattolica e regime fascista. Italia contemporanea, n. 194, p. 53-63, 1994.

MICHELAGNOLI, Giovanni. Amintore Fanfani: Dal corporativismo al neovolontarismo statunitense. Soveria Mannelli: Rubbettino, 2010.

MOLESTI, Romano. Il pensiero economico-sociale di Giuseppe Toniolo. In: (Ed.). Giuseppe Toniolo: Il pensiero el'opera. Milan: Franco Angeli, 2005, p. 131-167. 
MORTATI, Costantino. I limiti di una trasformazione corporativa dello Stato. Pagine libere, n. 10-12, p. 167ss, 1951. 1947.

La seconda camera. Cronache sociali, n. 9, p. 3-4,

NICOLOSO, Paolo. Genealogie del piano Fanfani. 19391950. In: DI BIAGI, Paola (Ed.). La grande ricostruzione: Il piano Ina-Casa e l'Italia degli anni Cinquanta. Rome: Donzelli, 2001.

ORNAGHI, Lorenzo. La concezione corporativa di Amintore Fanfani e il corporativismo fascista. Bollettino dell'Archivio per la storia del movimento cattolico-sociale in Italia, 1-2, 2011.

PASETTI, Matteo. L'Europa corporativa : una storia transnazionale tra due guerre mondiali. Bologna: Bonomia University Press, 2016.

(Ed.). Progetti corporativi tra le due guerre mondiali. Rome: Carocci, 2006.

PERSICO, Alessandro. Il codice di Camaldoli. La DC e la ricerca della "terza via" tra Stato e mercato (1943-1993). La nascita del "mito di Camaldoli". Milan: Guerini e Associati, 2014.

PIO XII. Discours et Messages-radio de S.S. Pie XII, VIII, Huitième année de pontificat, 2 mars 1946 - $1^{\text {er }}$ mars 1947. Rome: Typographie Polyglotte Vaticane, 1947. POLLARD, John. Corporatism and political Catholicism. The impact of Catholic corporatism in inter-war Europe. In: COSTA PINTO, Antonio (Ed.).
Corporatism and Fascism: The Corporatist Wave in Europe. London: Routledge, 2017, p. 42-59.

POMBENI, Paolo. La questione costituzionale in Italia. Bologna: il Mulino, 2016.

ROGGI, Piero. Amintore Fanfani: dal corporativismo all'istituzionalismo americano. In: GIRELLI BOCCI, Angela Maria. Amintore Fanfani: Storico dell'economia e statista. Economic Historian and Statesman. Milan: Franco Angeli, 2013, p. 71-83.

SANI, Roberto. La Civiltà Cattolica e la politica italiana nel secondo dopoguerra, 1945-1958. Milan: Vita e Pensiero, 2004.

SANTOMASSIMO, Gianpasquale. La terza via fascista: Il mito del corporativismo. Carocci: Rom, 2006.

SIMONE, Giulia. Il Guardasigilli del regime: L'itinerario politico e culturale di Alfredo Rocco. Milan: Franco Angeli, 2012.

STOLZI, Irene. L'ordine corporativo: Poteri organizzati e organizzazione del potere nella riflessione giuridica dell'Italia fascista. Giuffrè: Milan, 2007.

STURZO, Luigi. Del metodo sociologico (1950): Studi e polemiche di sociologia (1933-1958). Rubbettino: Soveria Mannelli, 2005.

VALLAURI, Carlo. Le radici del corporativismo. Rome: Bulzoni, 1971.

ZAGANELLA, Marco. Democratic Corporatism: The Italian debate during the "First Republic" (1948-1992). Estudos Ibero-Americanos, v. 42, n. 2, p. 430-453, 2016. 